\title{
Sosialisasi Sanksi Pidana Terhadap Pelaku Kejahatan Konservasi Sumber Daya Alam Hayati dan Ekosistemnya di SMK Negeri 7 Bandar Lampung
}

\author{
Lusi Apriyani ${ }^{1}$, Neisa Angrum Adisti ${ }^{2} \bowtie$ \\ Ilmu Hukum, Fakultas Hukum, Universitas Sriwijaya, Indonesia ${ }^{1,2}$ \\ E-mail: apriyani.lusi@gmail.com¹, neisa@unsri.ac.id ${ }^{2}$
}

\begin{abstract}
Abstrak
Kejahatan terhadap satwa liar terus terjadi. Bahkan pada awal tahun 2018, seekor orang utan tanpa kepala ditemukan mengambang di Desa Kalahien, Kecamatan Dusun Selatan, Kabupaten Barito Selatan, Kalimantan Tengah. Hasil autopsi ditemukan 17 peluru senapan angin di tubuh (jantung, paru-paru, dan lambung) orang utan tersebut dan luka-luka dari benda tajam, serta luka tebasan. Untuk memberikan pemahaman terutama kepada siswa SMK, maka diadakan sosialisasi sanksi pidana terhadap pelaku kejahatan konservasi sumber daya alam hayati dan ekosistemnya di SMK Negeri 7 Bandar Lampung. Metode yang dilakukan dalam penyuluhan adalah metode ceramah, diskusi, dan metode evaluasi. Dari penyuluhan hukum yang dilaksanakan di SMK Negeri 7 Kota Bandar Lampung dapat disimpulkan bahwa: siswa SMK Negeri 7 Kota Bandar Lampung sebagai peserta sosialisasi telah memahami pentingnya memberikan perlindungan terhadap satwa dan menjaga habitat satwa, siswa mengetahui tentang aturan hukum terkait perlindungan terhadap satwa. siswa memahami jenis-jenis tindakan yang dilarang dilakukan terhadap satwa beserta ketentuan pidananya, siswa telah memahami perannya dalam memberikan perlindungan satwa dan habitatnya.
\end{abstract}

Kata kunci: satwa liar, SMKN 7, sosialisasi

\begin{abstract}
Crime against wildlife continues. In early 2018, a headless orangutan was found floating in Kalahien Village, Dusun Selatan District, South Barito Regency, Central Kalimantan. From the autopsy results, 17 air rifle bullets were found in the orangutan's body (heart, lungs, and stomach) and injuries from sharp objects and slash wounds. To provide an understanding, especially to vocational students, a criminal sanction socialization was held against the perpetrators of crimes against the conservation of natural resources and their ecosystems at SMK Negeri 7 Bandar Lampung. The method used in this socialization is the lecture, discussion and evaluation method. from the legal counseling conducted at SMK Negeri 7 Bandar Lampung City, it can be concluded that: students of SMK Negeri 7 Bandar Lampung City as socialization participants have understood the importance of providing protection for animals and maintaining animal habitats, students know about legal rules related to animal protection, students understand the types of actions that are prohibited from being carried out on animals and their criminal provisions, students have understood their role in providing protection for animals and their habitats.
\end{abstract}

Keywords: wildlife, SMKN 7, socialization

Copyright (c) 2021 Lusi Apriyani, Neisa Angrum Adisti

$\triangle$ Corresponding author

Address : Universitas Sriwijaya

Email : neisa@unsri.ac.id

ISSN 2721- 9224 (Media Cetak)

DOI : https://doi.org/10.31004/abdidas.v2i3.327

ISSN 2721- 9216 (Media Online) 
574 Sosialisasi Sanksi Pidana Terhadap Pelaku Kejahatan Konservasi Sumber Daya Alam Hayati dan Ekosistemnya Di SMK Negeri 7 Bandar Lampung - Lusi Apriyani, Neisa Angrum Adisti

DOI: https://doi.org/10.31004/abdidas.v2i3.327

\section{PENDAHULUAN}

Indonesia terkenal dengan sumber daya alam yang melimpah, baik yang hayati dan non hayati. Letak Indonesia secara geografis pada garis khatulistiwa sangat menguntungkan, baik dari kondisi iklim, alam, maupun keanekaragaman sumber daya alam hayati. Indonesia menjadi rumah bagi $12 \%$ spesies mamalia, $7,3 \%$ spesies amfibi dan reptil dunia, serta $17 \%$ spesies burung (USAID, 2015). Menurut catatan USAID yang dikutip dari IUCN (2014) The IUCN Red List of Threatened Species version 2014.3, setidaknya terdapat 1.225 spesies flora dan fauna terancam punah (USAID, 2015).

Sayangnya, perlahan jumlah dan keanekaragaman jenis spesies semakin menurun, terutama jumlah satwa liar yang disebabkan oleh beberapa faktor di antaranya: (1) pembangunan; (2) instrumen hukum yang belum kuat; (3) perlindungan satwa yang belum menjadi prioritas pemerintah; (4) perdagangan illegal dan perburuan; (5) perubahan iklim, dan (6) rendahnya pengetahuan dan kesadaran masyarakat terhadap perlindungan satwa liar yang akhirnya berujung pada konflik manusia dan satwa liar (humanwildlife conflict) (Lusi Apriyani, 2017).

Sebenarnya Indonesia telah memiliki sejumlah aturan yang menjadi kerangka hukum perlindungan satwa di Indonesia yaitu Undangundang Nomor 5 Tahun 1990 tentang Konservasi Sumber Daya Alam Hayati dan Ekosistemnya yang merupakan undang-undang organik perlindungan satwa. Kemudian sejumlah perundang-undangan terkait yaitu Undang-undang Nomor 41 Tahun 1999 tentang Kehutanan,
Undang-undang Nomor 32 Tahun 2009 tentang Perlindungan dan Pengelolaan Lingkungan Hidup, Undang-undang Nomor 16 Tahun 1992 tentang Karantina Tanaman, Ikan dan Binatang, Undangundang Nomor 18 Tahun 2013 tentang Pencegahan dan Pemberantasan Perusakan Hutan, Undangundang Nomor 5 Tahun 1994 tentang Pengesahan United Nations Convention On Biological Diversity (Konvensi Perserikatan Bangsa-bangsa Mengenai Keanekaragaman Hayati), Undangundang Nomor 21 Tahun 2004 tentang Cartagen Protokol tentang Keamanan Hayati atas Konservasi tentang Keanekaragaman Hayati, serta Undang-undang Nomor 11 Tahun 2013 tentang Protokol Nagoya tentang Akses pada Sumber Daya Genetik dan Pembagian Keuntungan yang Adil dan Seimbang yang Timbul dari Pemanfaatannya atas Konservasi Keanekaragaman Hayati (Lusi Apriyani, 2017).

Pada tingkat aturan pelaksana Indonesia memiliki Peraturan Pemerintah Nomor 13 Tahun 1994 tentang Perburuan Satwa Buru. Peraturan Pemerintah Nomor 68 Tahun 1998 tentang Kawasan Suaka Alam dan Kawasan Pelestarian Alam, Peraturan Pemerintah Nomor 7 Tahun 1999 tentang Pengawetan Jenis Tumbuhan dan Satwa Peraturan Pemerintah Nomor 8 Tahun 1999 tentang Pemanfaatan Jenis Tumbuhan dan Satwa Liar. Selain undang-undang dan peraturan pemerintah yang disebutkan di atas, Indonesia masih memiliki Peraturan Menteri dan jenis-jenis peraturan perundang-undangan lainnya. Jika dilihat dari jumlah instrumen hukum di atas seharusnya jumlah spesies satwa liar di Indonesia 
575 Sosialisasi Sanksi Pidana Terhadap Pelaku Kejahatan Konservasi Sumber Daya Alam Hayati dan Ekosistemnya Di SMK Negeri 7 Bandar Lampung - Lusi Apriyani, Neisa Angrum Adisti

DOI: https://doi.org/10.31004/abdidas.v2i3.327

terus bertambah bukan sebaliknya (Indra Nugraha, 2018).

Faktanya, kejahatan terhadap satwa liar terus terjadi. Bahkan pada awal tahun 2018 seekor orang utan tanpa kepala ditemukan mengambang di Desa Kalahien, Kecamatan Dusun Selatan, Kabupaten Barito Selatan, Kalimantan Tengah. Dari hasil autopsi ditemukan 17 peluru senapan angin di tubuh (jantung, paru-paru, dan lambung) Orang utan tersebut dan luka-luka dari benda tajam serta luka tebasan(Anendya Nirvana, 2018). Pada akhir Januari, Kepolisian Kalimantan Tengah berhasil menangkap dua orang pelaku yang mengaku melakukan penembakan dan penebasan kepala orang utan dikarenakan orang utan tersebut memasuki perkebunan mereka dan tidak bisa diusir. Belum tuntas dengan penyelidikan kasus orang utan tanpa kepala, Indonesia kembali mengagetkan dunia internasional dengan ditemukannya orang utan yang mati dengan 130 luka tembak di tubuhnya di Taman Nasional Kutai (TNK) Kutai Timur (Kutim), Kalimantan Timur (Kaltim) pada 6 Februari 2018 (Nara, 2018). Seminggu kemudian, polisi menangkap lima pelaku pembunuh orang utan yang berdalih bahwa orang utan tersebut merusak kebun mereka yang berlokasi di dalam Taman Nasional Kutai (Aditya Mardiastuti, 2018).

Berdasarkan data yang dihimpun oleh Centre for Orangutan Protection (COP) bekerja sama dengan Orangutan Foudantion International (OFI) Pangkalan Bun, dan Borneo Orangutan Survival Foundation (BOSF) Palangka Raya terdapat 10 kasus kejahatan terhadap orang utan di Kalimantan Tengah yang belum terungkap
(Nugroho Budi Baskoro, 2018). Kemudian, hasil studi yang dilakukan sejumlah ilmuwan yang dipublikasikan pada jurnal Current Biology menunjukkan bahwa orang utan Borneo mengalami kehilangan populasi sebanyak 100.000 dalam rentang waktu tahun 1999-2015 yang diperkirakan akan terus mengalami penurunan populasi (Maria Voigt, 2018).

Selain konflik manusia-satwa liar, ancaman kepunahan terhadap sejumlah spesies endemik Indonesia adalah perdagangan illegal satwa yang dilindungi. Indonesia menjadi "salah satu dari 10 besar negara "mega-diversivitas" dan pemasok terbesar produk satwa liar di Asia, baik secara legal maupun illegal'(USAID, 2015). UNODC (The United Nations Convention against Transnational Organized Crime) mengkategorikan perdagangan satwa liar sebagai "transnational organized wildlife crime" (UNODC, 2018).

Provinsi Lampung dengan Ibukota Bandar Lampung menjadi target sasaran kegiatan sosialisasi pelaksana. Pilihan ini dikarenakan kondisi dan potensi wilayah dari Provinsi Lampung sendiri memiliki keanekaragaman hayati yang unik. Salah satu satwa yang terkenal dari Provinsi Lampung dan menjadi incaran para pemburu adalah Gajah Sumatera (Elephas maximus sumatranus). Adapun fauna khas Lampung adalah bunga Ashar (Mirabilis Jalapa) yang dikenal dengan bunga sore atau bunga pukul empat sore.

Secara geografis, Provinsi Lampung dibatasi oleh: Provinsi Sumatera Selatan dan Bengkulu di sebelah utara, Selat Sunda di sebelah selatan, Laut Jawa di sebelah timur, dan Samudra Indonesia di 
576 Sosialisasi Sanksi Pidana Terhadap Pelaku Kejahatan Konservasi Sumber Daya Alam Hayati dan Ekosistemnya Di SMK Negeri 7 Bandar Lampung - Lusi Apriyani, Neisa Angrum Adisti

DOI: https://doi.org/10.31004/abdidas.v2i3.327

sebelah barat. Berdasarkan data statistik Badan Pusat Statistik (BPS) Provinsi Lampung tercatat jumlah penduduk Provinsi Lampung tahun 2017 adalah 8.289.577 jiwa yang terdiri atas 4.247.121 jiwa penduduk laki-laki dan 4.042.456 jiwa penduduk perempuan. Dari total jumlah penduduk tersebut, tingkat partisipasi angkatan kerja adalah sebesar $67,83 \%$, sedangkan tingkat pengangguran sebesar 4,33\%. Angka partisipasi murni paling tinggi ada di jenjang pendidikan SD/MI dengan nilai 99,02, sementara yang terendah adalah SMA/ SMK/ MA dengan nilai sebesar 58,97 (Badan Pusat Statistik Provinsi Lampung, 2018). Jumlah sekolah di Provinsi Lampung sesuai jenjang sekolah adalah sebagai berikut: Sekolah Dasar sebanyak 4688, Madrasah Ibtidaiyah sebanyak 775, Sekolah Menengah Pertama sebanyak 1358, Madrasah Tsanawiyah sebanyak 686, Sekolah Menengah Atas sebanyak 975 dan, Madrasah Aliyah sebanyak 306 (Badan Pusat Statistik Provinsi Lampung, 2018).

Adapun tujuan dari kegiatan penyuluhan ini adalah :

1. Untuk mensosialisasikan kepada masyarakat Lampung pada umumnya dan siswa pada khususnya tentang sanksi pidana terhadap pelaku kejahatan konservasi sumber daya alam hayati dan ekosistemnya.

2. Sebagai sarana sharing ilmu kepada siswa SMK di Lampung terutama mengenai bahaya kejahatan konservasi sumber daya hayati dan ekosistemnya dan ancaman pidananya.
3. Sebagai sarana pencegahan kejahatan konservasi sumber daya hayati dan ekosistemnya.

\section{METODE}

Dengan melihat sifat dari kegiatan dari penyuluhan hukum ini, maka penyuluhan dilaksanakan dengan metode/ cara sebagai berikut:

\section{Ceramah}

Metode yang dipakai adalah penyuluhan atau ceramah kepada peserta yaitu siswa SMK Negeri 7 Bandar Lampung dengan cara tatap muka langsung. Tim penyuluh menyampaikan materi yang telah disusun dengan menggunakan slide power point sebagai sarana memberikan informasi tentang sanksi pidana terhadap kejahatan konservasi. Ceramah akan disampaikan dengan metode interaktif yaitu dengan mengajak siswa berpatisipasi langsung pada saat penyampaian materi. Kemudian diberikan kesempatan yang seluas-luasnya kepada peserta untuk berdiskusi dan menyampaikan pendapatnya tentang materi yang disampaikan oleh tim penyuluh.

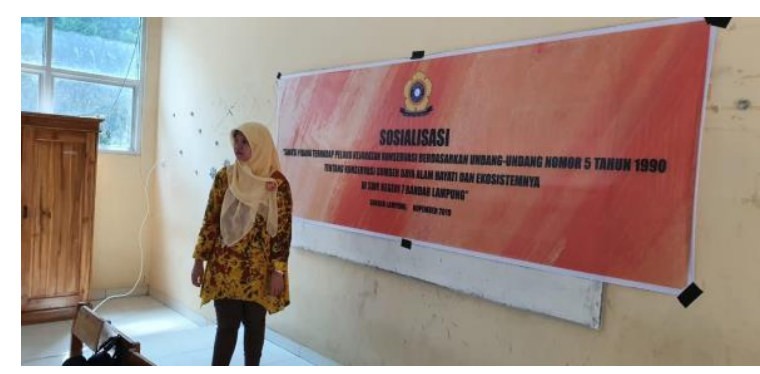

Gambar 1. Metode Ceramah di Depan Kelas

\section{Diskusi}

Dengan mengadakan tanya jawab antara tim penyuluh dan peserta, diharapkan mencapai satu 
577 Sosialisasi Sanksi Pidana Terhadap Pelaku Kejahatan Konservasi Sumber Daya Alam Hayati dan Ekosistemnya Di SMK Negeri 7 Bandar Lampung - Lusi Apriyani, Neisa Angrum Adisti

DOI: https://doi.org/10.31004/abdidas.v2i3.327

pemahaman tentang perlindungan satwa dan habitatnya serta aturan hukumnya.

\section{Metode Evaluasi}

Terlebih dahulu penyuluh mempersiapkan materi dan bahan sosialisasi. Selanjutnya penyuluh bersama timnya melakukan sosialisasi di SMK Negeri 7 Bandar Lampung. Keberhasilan kegiatan sosialisasi ini adalah apabila para siswa dapat mengerti dan memahami upaya perlindungan terhadap satwa dan tumbuhan sesuai dengan ketentuan UU No. 5 Tahun 1990 serta sanksi pidana terhadap pelaku kejahatan konservasi. Selain itu, siswa-siswa dapat menginformasikan hal tersebut kepada teman-temannya dan orang sekitarnya, serta berpartisipasi dalam upaya perlindungan satwa dan ekosistem.

Guna mengetahui tercapai tidaknya tujuan pengabdian diadakan umpan balik berupa pertanyaan-pertanyaan yang berkaitan dengan bantuan hukum yang baru saja diperoleh dari penyuluhan yang telah disampaikan yang mengungkapkan seluruh materi yang telah disajikan. Jika peserta penyuluhan telah menguasai $75 \%$ dari materi yang disajikan maka mereka dianggap berhasil. Jika ternyata hasilnya kurang dari $75 \%$, maka akan diperjelas lagi terutama untuk subpokok bahasan yang dianggap tidak dipahami oleh peserta penyuluhan.

\section{HASIL DAN PEMBAHASAN}

Pelaksanaan kegiatan ini dilakukan dengan mempersiapkan semua bahan-bahan yang berkaitan dengan kegiatan, yaitu pengumpulan literatur dengan cara library research atau studi penelusuran kepustakaan baik dari buku-buku maupun studi literatur dari web internet yang berkaitan langsung dengan materi yang akan diberikan dalam penyuluhan. Kemudian semua data disusun sebagai bahan untuk penyuluhan. Kegiatan penyuluhan hukum ini dilaksanakan pada: hari/tanggal Selasa, 12 November 2019, pukul 09.00 sampai dengan 12.00, yang dilaksanakan di ruang kelas SMK Negeri 7 Bandar Lampung.

Peserta dalam kegiatan ini adalah siswa kelas XI sejumlah 50 orang. Pelaksanaan penyuluhan di ruang kelas SMK Negeri 7 Bandar Lampung. Penyuluhan dilakukan dengan menggunakan metode paparan dan diskusi tanya jawab yang melibatkan 50 siswa sebagai peserta untuk berperan serta aktif dalam kegiatan penyuluhan setelah mendengar dari narasumber.

\section{Realisasi Pemecahan Masalah}

Pemberian perlindungan satwa masih oleh masyarakat masih sangat minim karena masyarakat beranggapan bahwa satwa liar merupakan ancaman bagi mereka, baik mengancam nyawa, permukiman, perkebunan, maupun ternak. Sehingga jika satwa liar masuk ke pemukiman penduduk dikarenakan habisnya sumber makanan dan rusaknya habitat, masyarakat secara bersama-sama memburu dan membunuh satwa tersebut. Sehingga ancaman kepunahan satwa tidak hanya berasal dari ancaman iklim dan pembangunan ekonomi namun juga dari masyarakat sendiri.

Terkait hal tersebut terdapat beberapa persoalan yang dihadapi, yaitu: 
578 Sosialisasi Sanksi Pidana Terhadap Pelaku Kejahatan Konservasi Sumber Daya Alam Hayati dan Ekosistemnya Di SMK Negeri 7 Bandar Lampung - Lusi Apriyani, Neisa Angrum Adisti

DOI: https://doi.org/10.31004/abdidas.v2i3.327

a. Jumlah satwa di Indonesia mulai mengalami penurunan.

b. Kurangnya pemberian perlindungan terhadap satwa.

c. Kurangnya pemahaman mengenai peraturan perundang-undangan tentang perlindungan satwa dan habitatnya

d. Kurangnya pemahaman mengenai peran masyarakat dalam pemberian perlindungan terhadap satwa dan habitat.

Atas permasalahan di atas, Tim Penyuluhan Hukum Fakultas Hukum Universitas Sriwijaya melakukan Sosialisasi Sanksi Pidana Terhadap Pelaku Kejahatan Konservasi Berdasarkan Undang-Undang Nomor 5 Tahun 1990 tentang Konservasi Sumber Daya Alam Hayati dan Ekosistemnya di SMK Negeri 7 Bandar Lampung dengan memberikan pengetahuan melalui paparan (presentasi), diskusi, maupun tanya jawab perihal:

1. Perlindungan hukum terhadap satwa di Indonesia.

2. Struktur dan ruang lingkup UU No. 5 Tahun 1990.

3. Definisi dan ruang lingkup konservasi dan pengawetan jenis tumbuhan dan satwa.

4. Ketentuan pidana dalam UU No. 5 Tahun 1990.

5. Peran serta masyarakat, khususnya siswa, dalam perlindungan satwa.

\section{Respon Balik dari Khalayak Sasaran}

Kegiatan penyuluhan hukum ini mendapat respon yang baik dari pihak sekolah maupun para siswa. Hal ini terlihat dari banyaknya siswa yang menjadi peserta dari penyuluhan hukum ini dan dukungan pihak sekolah terhadap penyelenggaraan penyuluhan hukum.

Tanggapan dari peserta didik juga terlihat antusian dan menyimak materi paparan Tim Penyuluhan Hukum. Terdapat kurang lebih 8 orang yang berpartisipasi dalam bentuk diskusi dan tanya jawab dalam waktu yang dibatasi. Kemudian, Tim Penyuluh juga memberikan pertanyaan kepada beberapa siswa sebagai bentuk evaluasi dan siswa-siswa tersebut mampu menjawab dengan tepat pertanyaan dari Tim Penyuluhan Hukum.

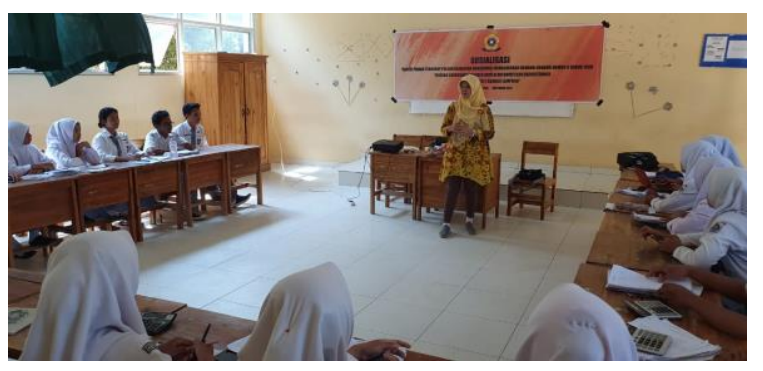

Gambar 1 Antusiasme Peserta

\section{Hasil Evaluasi dan Pembahasan}

Kegiatan penyuluhan ini dilakukan dengan tiga tahap. Tahap pertama sebelum materi penyuluhan dimulai, tim penyuluhan hukum melakukan ice breaking dengan permainan yang melibatkan peserta dalam games tersebut. Setelah membangkitkan semangat siswa, tim penyuluhan hukum melanjutkan ke tahap kedua yaitu pemaparan dari tim penyuluh dari Fakultas Hukum UNSRI yang diawali dengan memberikan beritaberita tentang habitat satwa yang rusak, perburuan liar, penyelundupan satwa, dan tindakan manusia terhadap satwa. Kisah tersebut menjadi hal penting untuk menarik minat siswa menyimak presentasi 
579 Sosialisasi Sanksi Pidana Terhadap Pelaku Kejahatan Konservasi Sumber Daya Alam Hayati dan Ekosistemnya Di SMK Negeri 7 Bandar Lampung - Lusi Apriyani, Neisa Angrum Adisti

DOI: https://doi.org/10.31004/abdidas.v2i3.327

Tim Penyuluhan Hukum. Kemudian paparan dilanjutkan dengan menjelaskan aturan hukum yang mengatur perihal perlindungan satwa yaitu Undang-undang Nomor 5 Tahun 1990 tentang Konservasi Sumber Daya Alam Hayati dan Ekosistemnya; struktur dan ruang lingkup UU No. 5 Tahun 1990; definisi dan ruang kingkup konservasi dan pengawetan jenis tumbuhan dan satwa; ketentuan pidana dalam UU No. 5 Tahun 1990, dan; peran serta masyarakat, khususnya siswa, dalam perlindungan satwa.

Tahap ketiga adalah diskusi dan tanya jawab perlindungan satwa dan habitatnya, baik dari sisi aturan hukum maupun dari peran serta yang dapat dilakukan oleh siswa. Tahapan ini merupakan tahap evaluasi yaitu untuk mengetahui perubahan sikap dan peningkatan pengetahuan siswa terhadap aturan hukum dan perilaku yang berkaitan dengan perlindungan satwa.

Dari serangkaian kegiatan di atas, penyuluh dapat melihat bahwa pengetahuan siswa terhadap aturan hukum mengenai perlindungan satwa dan habitat masih sangat minim. Namun setelah adanya materi dari penyuluh, terlihat bahwa siswa mulai memahami apa itu perlindungan terhadap satwa dan juga tindakan-tindakan yang dilarang dilakukan terhadap satwa dan habitatnya. Hal tersebut dapat disimpulkan dari jenis-jenis pertanyaan yang diajukan siswa kepada pemateri yang sebagian besar dikaitkan dengan apa yang mereka lihat dan alami di lingkungan sekitarnya.

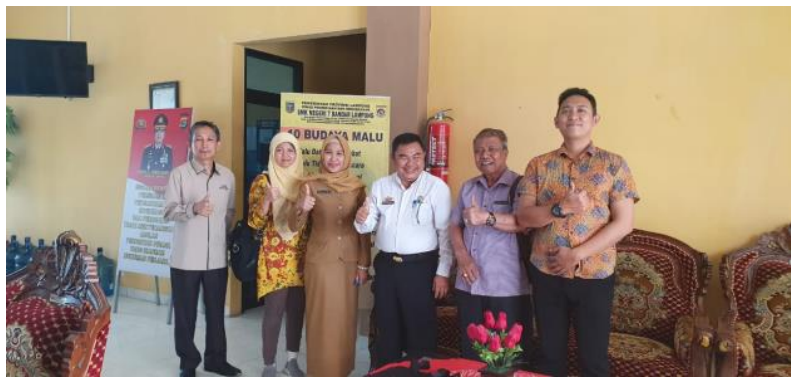

Gambar 2. SMK N 7 Bandar Lampung

\section{SIMPULAN}

Menurunnya jumlah satwa liar di Indonesia bukan hanya disebabkan oleh perubahan iklim dan dampak negatif dari pembangunan, namun juga sikap masyarakat terhadap satwa liar yang menganggap bahwa satwa liar adalah ancaman. Peran akademisi hukum dalam meningkatkan kesadaran tentang pentingnya memberikan perlindungan terhadap keberadaan satwa dan habitatnya adalah dengan melaksanakan penyuluhan hukum tentang Undang-Undang Nomor 5 Tahun 1990 tentang Konservasi Sumber Daya Alam Hayati dan Ekosistemnya; struktur dan ruang lingkup UU No. 5 Tahun 1990.

Dari penyuluhan hukum yang dilaksanakan di SMK Negeri 7 Kota Bandar Lampung dapat disimpulkan bahwa:

1. Siswa SMK Negeri 7 Kota Bandar Lampung sebagai peserta sosialisasi telah memahami pentingnya memberikan perlindungan terhadap satwa dan menjaga habitat satwa.

2. Siswa mengetahui tentang aturan hukum terkait perlindungan terhadap satwa.

3. Siswa memahami jenis-jenis tindakan yang dilarang dilakukan terhadap satwa beserta ketentuan pidananya. 
580 Sosialisasi Sanksi Pidana Terhadap Pelaku Kejahatan Konservasi Sumber Daya Alam Hayati dan Ekosistemnya Di SMK Negeri 7 Bandar Lampung - Lusi Apriyani, Neisa Angrum Adisti

DOI: https://doi.org/10.31004/abdidas.v2i3.327

4. Siswa telah memahami perannya dalam memberikan perlindungan satwa dan habitatnya.

\section{UCAPAN TERIMA KASIH}

Terima kasih kepada semua pihak yang sudah membantu terlaksananya kegiatan penyuluhan ini dengan baik terutama kepada SMK Negeri 7 Bandar Lampung.

\section{DAFTAR PUSTAKA}

Aditya Mardiastuti. (2018). Polisi Tangkap 5 Orang Pembunuh Orang Utan Di Kalimantan Timur.

Anendya Nirvana. (2018). Fakta Mengerikan Di Balik Kematian Orangutan Tanpa Kepala. 22 JAN 2018.

Badan Pusat Statistik Provinsi Lampung. (2018). Provinsi Lampung Dalam Angka.

Indra Nugraha. (2018). Menyedihkan, Satu Individu Orangutan Ditemukan Mengambang Tanpa Kepala. Diakses Pada 23 Januari 2018.

Lusi Apriyani. (2017). Perbandingan Hukum Perlindungan Satwa Indonesia dan Amerika Serikat Dalam Rangka Reformasi Undangundang Nomor 5 Tahun 1990 tentang Konservasi Sumber Daya Alam Hayati dan Ekosistemnya.

Maria Voigt, et. a. (2018). Global Demand for Natural Resources Eliminated More Than 100,000 Bornean Orangutans, Current Biology.

Nara, G. (2018). Satu Orangutan Tewas dengan 130 Luka Tembak di TNK Kaltim.

Nugroho Budi Baskoro. (2018). Polisi Tangkap Pemenggal Kepala Orangutan di Kalimantan Tengah, .

UNODC. (2018). Defining Transnational Organized Wildlife Crime,

USAID. (2015). Perdagangan Satwa Liar, Kejahatan terhadap Satwa Liar dan
Perlindungan Spesies di Indonesia: Konteks Kebijakan dan Hukum Changes For Justice Project. USAID. 